\title{
ソフト磁性材料の材料欠陥と強磁性粉末による修復効果
}

\author{
草加 勝司，木村 大輔 \\ 大同工業大学, $\overline{7} 457-0811$ 名古屋市南区大同町 2-21.
}

\section{Geometrical Defect of Soft-Magnetic Material and Its Magnetic Restoration by Ferromagnetic Powder}

\author{
Katsushi Kusaka and Daisuke Kimura \\ Daido Institute of Technology, 2-21 Daido-cho Minami-ku, Nagoya 457-0811.
}

Received January 7,1999

\section{SYNOPSIS}

The objective of this study is firstly to elucidate the effect of geometrical defect (artificial semi/full slit) on magnetic properties and secondly to evaluate the magnetic restoration by ferromagnetic paste filling to slit for the 4-types of soft magnetic materials. In this case, ferromagnetic pastes consist of the mixture of water-atomized powder of almost the same type (as specimen) and binding agent.

The results obtained were summarized as follows:

(1) DC magnetic properties are more or less degraded by semi/full slit, where magnetic induction (B) are less degraded in comparison with maximum permeability $(\mu \mathrm{m})$, especially for high- $\mu$ permalloy.

(2) AC magnetic properties, especially, specific permeability ( $\mu$ a) are degraded nearly in the same way as DC ones in low frequency range and less degraded at higher frequency (degradation ratio $\Delta \mu \mathrm{a} / \mu \mathrm{a}<0.1,100 \mathrm{kHz}$ ).

(3) As for DC magnetic properties, magnetic induction (B) tends to be more restored than maximum permeability $(\mu \mathrm{m})$ by ferromagnetic paste filling to slit, although fairly plot-scattered.

(4) AC magnetic properties at $60 \mathrm{~Hz}$ also are enhanced upto restoration ratio $\Delta \mu \mathrm{a}^{\prime} / \Delta \mu \mathrm{a} \sim 1 / 2$ roughly by ferromagnetic paste filling to full slit, almost irrespectively of material type and slit width.

(5) This ferromagnetic paste method is more effective in DC or low frequency range due to the result that $\Delta \mu \mathrm{a} / \mu \mathrm{a}$ is fixed small for semi slit and linearly decreases for full slit with rise of applied frequency.

\section{KEYWORDS}

magnetic properties, geometrical defect, ferromagnetic paste, magnetic degradation, magnetic restoration

\section{1 緒言}

ソフト磁性材料は電子機器類を中心に家電, 自動車等の各 種分野で使用され，最近では過酷な環境条件下で使用される 場合も多くなっている. 例えば各種電磁弁や駆動系のヨーク 類, センサー類などでは DC/AC磁気特性以外に耐磨耗性や耐 腐食性が磁性材料の選定要因 ${ }^{1)}$ となりうる.ところで, 通常り フト磁性材料と称される $\mathrm{Fe}-\mathrm{Si}, \mathrm{Fe}-\mathrm{Cr}, \mathrm{Fe}-\mathrm{Ni}$ などを基本組成と した磁性合金は構造敏感 2)で，材料欠宿や応力歪み等の外的 要因により本来の磁気特性が損なわれやすい.

そこで，代表的なりフト磁性合金を対象に材料欠陥を人為 的に入れ，材料欠陷(症) に伴う DC/AC 磁気特性の劣化を定 量的に評価するとともに，その欠陥箇所に同材質の強磁性粉
末ペーストを充填・修復することにより，本来の磁気特性が どの程度回復可能か, 基本的モデルについて検討することと した.

\section{2 試料および実験方法}

電気炉溶解し，低炭素化して得たインゴットを鍛造・圧延 することにより 4 種類の棒材: 電磁純鉄 $(\mathrm{A})$, 電磁ステンレス 鋼 $(\mathrm{B}, \mathrm{C}), \mathrm{PC}$ パーマロイ合金 (D) を製造した。

Table 1 に棒材の化学成分を示す.この内, 電磁ステンレス 鋼は $\mathrm{Fe}-13 \mathrm{Cr}$ を主成分とする が，Cは基本鋼種 $\mathrm{B}$ の $\mathrm{Al}$ を $1 \%$ に増量し，電気抵抗の増大による交流・実効透磁率を改良 ${ }^{4}$ し，可動部分に適用したものである. 
これら棒材より一般的で反磁界2)のない巻鉄芯)を想定した 環状試験片 $(45 \phi \times 33 \phi \times 5 \mathrm{~mm})$ を切り出し, 真空加熱炉中, A C試料は $1173 \mathrm{~K} ， \mathrm{D}$ 試料は $1373 \mathrm{~K}$ で $60 \mathrm{~min}$ 徐冷の磁気焼鈍点を 施した.続いてワイヤーカットにより環状試験片の一部に0.3, $0.6,1 \mathrm{~mm}$ 幅の並びに 0.3 ( $\mathrm{mm}$ 幅：以後省略) $/ 2,4,6 \mathrm{~mm}$ 深さ (6mm は貫通孔) の空隙を入れた.

Fig.1にこれら战モテルの形状と寸法を明示した. 直流(AD) 磁気測定は B-H カーフ・・トレーサー(理研電子製)を使用し， 最大印加磁界はもとの磁化曲線が十分飽和する $\mathrm{A} \sim \mathrm{C}$ 試料で $2000 \mathrm{~A} / \mathrm{m}$ (250e), 高透磁率系 ${ }^{1}$ の D 試料で $800 \mathrm{~A} / \mathrm{m}$ (100e) に設 定した. また交流 $(\mathrm{AC})$ 磁気測定は B-Hアナライザー(岩崎通 信製)を使用し，最大印加磁界は $240 \mathrm{~A} / \mathrm{m}^{7}$ (3Oe) とし，60 Hz $100 \mathrm{kHz}$ の周波数領域で測定した. 以上の測定結果から, 空隙 による磁気特性 $\mathrm{X}$ の変化 (劣化率 $=\Delta \mathrm{X} / \mathrm{X}$ ) を算出した.

次に A, B(C), D 試料とほぼ同じ 3 種類の噴罞粉末 (Table 2) に塩ビ酢ビ共重合樹脂(ソルバイン A：日信化学工業製) $2 \mathrm{wt} \%$ と溶剂を混入して強磁性ペーストを調整し,久損箁所に圧入・ 乾燥し，もとの環状試験片の形にした.これら 4 種類の A D D 補修試料について，前記と同じ手段で直流・交流磁気測定を 行い，磁気特性の回復率 $\left(=\Delta X^{\prime} / \Delta X,=1\right.$ で $100 \%$ 回復)を算出し た。ここの際使用した強磁性粉末は水噴霧法 ${ }^{8}$ により製造され

Table 1 Chemical compositions of specimens

wt.\%

\begin{tabular}{|c|c|c|c|c|c|c|c|c|c|}
\hline Type & C & Si & Mn & P & S & Ni & Cr & Mo & Al \\
\hline A & 0.002 & 0.10 & 0.16 & 0.008 & 0.001 & 0.03 & 0.04 & 0.01 & 0.01 \\
\hline B & 0.013 & 0.84 & 0.28 & 0.020 & 0.014 & 0.11 & 13.05 & 0.02 & 0.25 \\
\hline C & 0.006 & 0.06 & 0.12 & 0.021 & 0.001 & 0.07 & 12.90 & 0.01 & 1.04 \\
\hline D & 0.010 & 0.10 & 0.57 & 0.004 & 0.001 & 77.97 & 0.05 & 4.33 & 0.01 \\
\hline
\end{tabular}

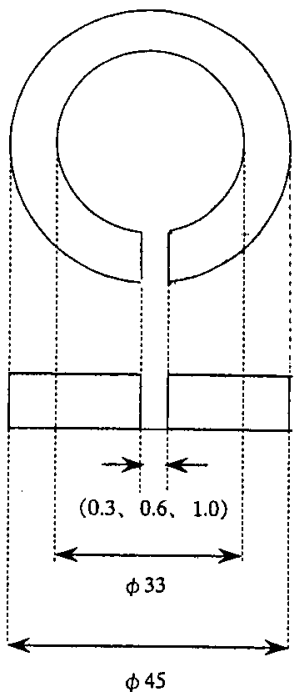

Full slit
Semi slit

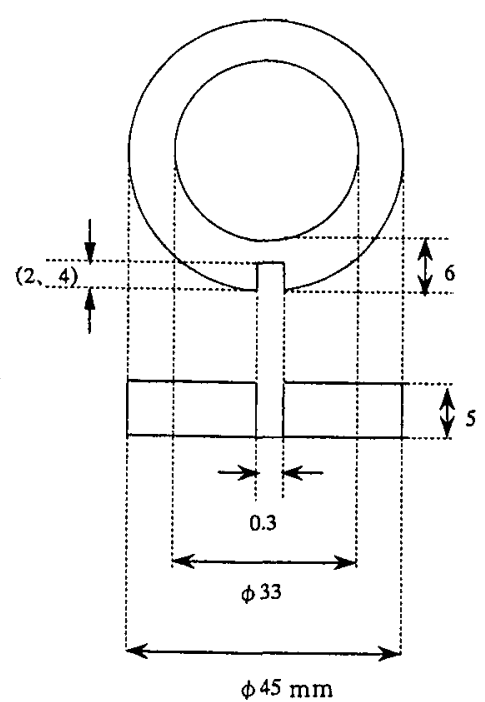

Fig.1 Illustration of geometrical defect model.
た合金粉末を 350 メッシュ $(40 \mu \mathrm{m})$ 以下に筛分けたもので， 粉末粒形は走查型電子顕微鏡により観察した。ただし，純鉄

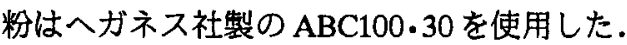

\section{3 実験結果および考察}

\section{1 材料久陥の影響}

Fig.2にフェライト系ステンレス鋼のC試料と，それに0.31

Table 2 Chemical compositions of Powders.

$w t \%$

\begin{tabular}{|c|c|c|c|c|c|c|c|c|}
\hline Type & $\mathrm{C}$ & $\mathrm{Si}$ & $\mathrm{Mn}$ & $\mathrm{P}$ & $\mathrm{S}$ & $\mathrm{Ni}$ & $\mathrm{Cr}$ & $\mathrm{Mo}$ \\
\hline $\mathrm{A}$ & 0.001 & 0.01 & 0.05 & 0.003 & 0.003 & 0.02 & 0.01 & 0.01 \\
\hline $\mathrm{B}(\mathrm{C})$ & 0.013 & 0.80 & 0.18 & 0.021 & 0.005 & 0.09 & 12.35 & - \\
\hline $\mathrm{D}$ & 0.002 & 0.97 & 0.01 & 0.001 & 0.002 & 79.62 & - & 4.20 \\
\hline
\end{tabular}

A: Haganas ABC100.30
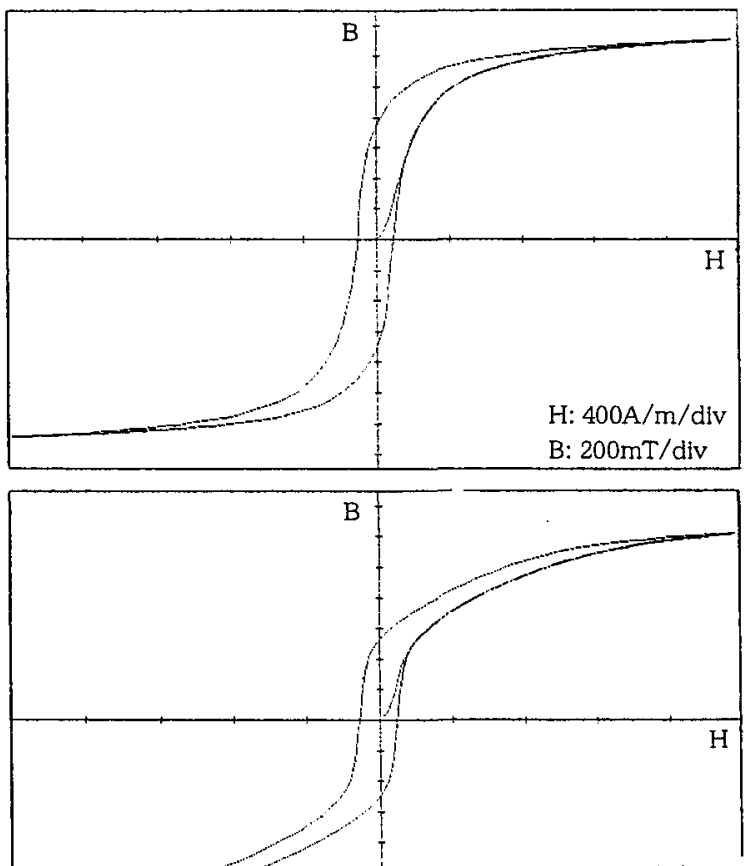

Slit width: $0.3 \mathrm{~mm}$ depth: $4.0 \mathrm{~mm}$

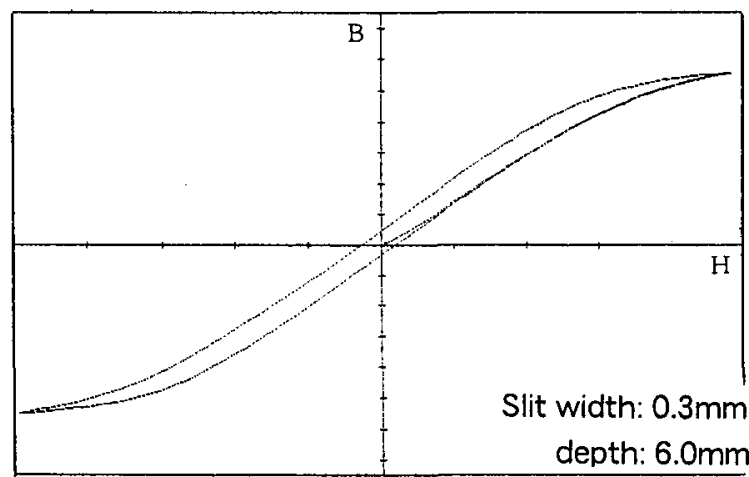

Fig.2 Example of DC B-H curves (C-type) 
4, 6mm 深さの空隙を入れた場合の直流磁界中での B-H曲線の 測定例を示す．もとの試料の B-H曲線に比べ，空隙を入れる とヒステリシス曲線が撫肩になり，曲線の立上がりが遅く， 磁束密度 Bが飽和しにくくなる傾向が見られる。ささらに $0.3 \mathrm{~mm}$ 幅の貫通孔に至っては，エヤーギャッブにおける磁気 抵抗 ${ }^{5}$ が急增し， B/Hがほほ一定の常磁性的な挙動をとる。そ こで $\mathrm{A} \sim \mathrm{D}$ 試料の直流 $\rightarrow$ 交流磁気特性と空隙パラメーター (幅，深さ)との関係について検討した.

Fig.3, 4 に A 〜D試料のもとの磁束密度 $\mathrm{B}$ ，最大透磁率 $\mu \mathrm{m}$ に 対し，空隙を入れたときの特性の劣化率 $\Delta \mathrm{B} / \mathrm{B}, \Delta \mu \mathrm{m} / \mu \mathrm{m}$ と空隙 パラメーターとの関係を示す。ただし，以後磁束密度 $\mathrm{B}$ は $\mathrm{A}$ $\sim \mathrm{C}$ 試料で $2000 \mathrm{~A} / \mathrm{m}$ ，D試料で $800 \mathrm{~A} / \mathrm{m}$ の印加磁界における読 取り值とした. 各試料とも，磁束密度 $\mathrm{B}$ は空隙の幅が広がる につれ漸減し， $1 \mathrm{~mm}$ 幅で $\Delta \mathrm{B} / \mathrm{B} \sim 1 / 2$ 近くまで劣化するが， Fig.3の下図( $0.3 \mathrm{~mm}$ 幅 $)$ から $\Delta \mathrm{B} / \mathrm{B}$ と深さとの関係は直線的で， 比較的変化は小さいことが分かる. 他方, Fig.4の最大透磁率 $\mu \mathrm{m}$ は空隙の幅, 深さに対し敏感に変化し, 貫通孔の場合, $0.3 \mathrm{~mm}$ 幅で既に $\Delta \mu \mathrm{m} / \mu \mathrm{m}$ は 0.8 以上に達する．また Fig.4の下 図から，前記磁束密度 B とは異なり， $\Delta \mu \mathrm{m} / \mu \mathrm{m}$ は深さに対し 上にやや彎曲した曲線となり，特に高透磁率材料として知ら れる ${ }^{1)} \mathrm{D}$ 試料での特性劣化が目立つ。なお保磁力 $\mathrm{Hc}$ に関して

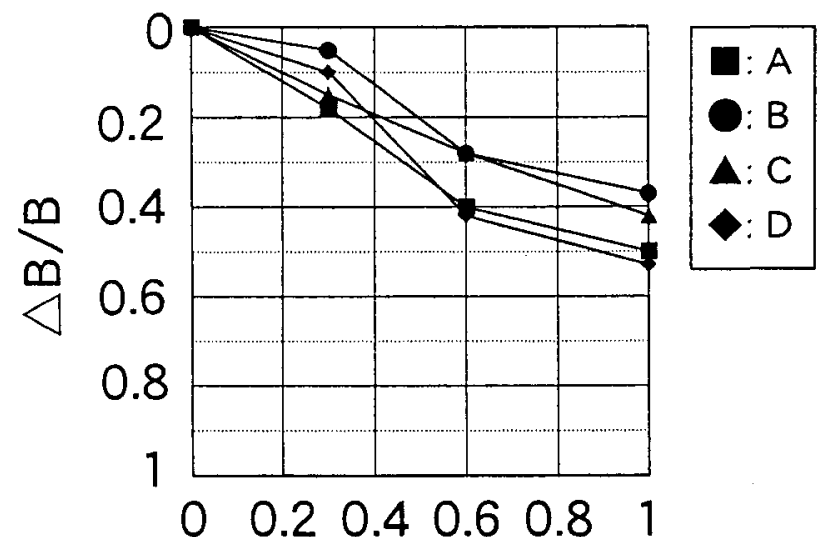

Slit width, $\mathrm{mm}$

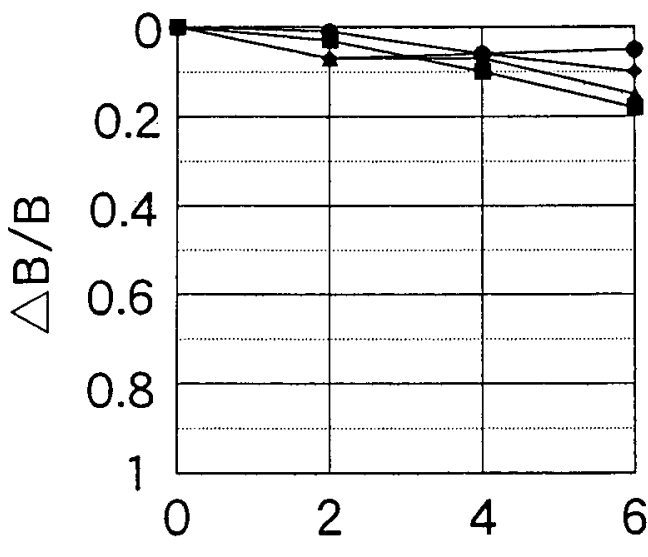

Slit depth, $\mathrm{mm}$

Fig.3 Effect of slit geometry on magnetic induction (B).
は, Fig.1から予測される反磁界の影響】で見掛け上 $\Delta \mathrm{Hc} / \mathrm{Hc}<1$ となるが, 数值化は意味がないため検討対象から外し，最大/ 比透磁率 (後出)で代表させた.

Fig.5に Fig.2 と同じ C 試料と，それに $0.3 / 4,6 \mathrm{~mm}$ 深さの空 隙を入れた場合の交流磁界中での B-H 曲線の測定例を示す。 ここで B-H曲線，つまりヒステリシスループは外側より $60 \mathrm{~Hz}$, $1,10,100 \mathrm{kHz}$ の順であり，全体的に周波数が高くなるにつれ 縦につぶれ，最大磁束密度 Bmが低下しているものの，0～ $4 \mathrm{~mm}$ 深さでは変化は小さい. しかし0.3mmの貫通孔になると， ヒステリシスループの変化が目立つ(縦軸の単位が異なる).

Fig.6に A D 試料のもとの振幅比透磁率 $\mu \mathrm{a}(=\mathrm{Bm} / \mathrm{Hm} \cdot \mu \mathrm{0}$ : 以後比透磁率と略称)に対し，空隙を入れたときの $60 \mathrm{~Hz}$ 交流 磁界中での特性の劣化率 $\Delta \mu \mathrm{a} / \mu \mathrm{a}$ と空隙バラメーターとの関係 を示す.この際，交流磁気特性は Fig.4で劣化率が大きく，か つ Bm と比例関係》にある比透磁率で代表させた. 前記直流磁 気特性 $(\mu \mathrm{m})$ と比べ劣化率レベルは低いが, 各試料とも空隙が 貫通した，つまり Fig.6の上図でいえば0.3mm幅となった時点 で比透磁率 $\mu \mathrm{a}$ はもとの試料の $1 / 2$ 以下に急減している。しか し，Fig.6の下図の深さによる変化からも，空隙が試料を貫通 (右端)しない限り比透磁率 $\mu \mathrm{a}$ の劣化程度は小さいことが分か る。
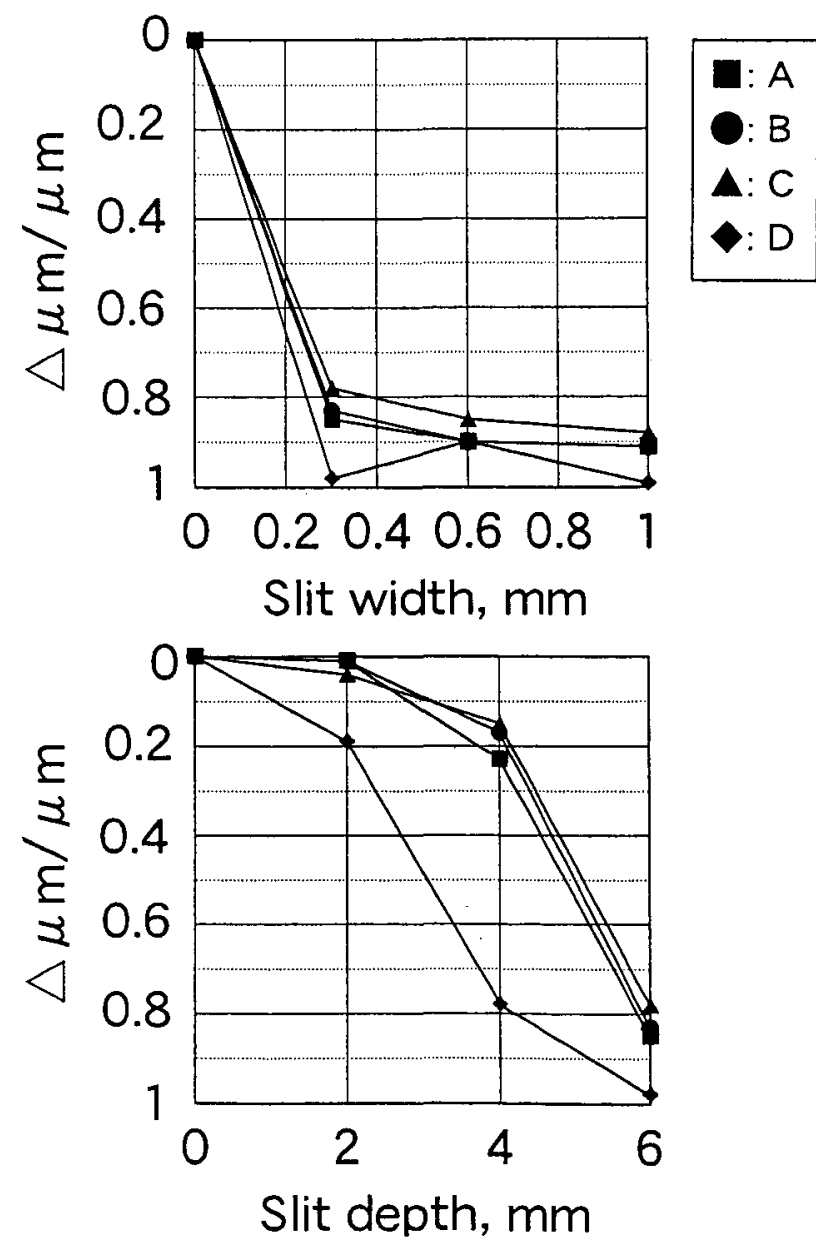

Fig.4 Effect of slit geometry on maximum permeability $(\mu \mathrm{m})$. 
以上の結果より，直流/交流磁界中での磁気特性は材質・空隌 間の相互作用が異なり，周波数依存性が大きことが想定される.

そこでFig.7にA〜D試料に空隙を入れたときの比透磁率 $\mu \mathrm{a}$ の劣化率 $\Delta \mu \mathrm{a} / \mu \mathrm{a}$ と測定周波数との関係をまとめた. いずれの 試料の比透磁率 $\mu \mathrm{a}$ も空腺が試料を貫通した状態では $60 \mathrm{~Hz} \rightarrow$ $100 \mathrm{kHz}$ と周波数が增加するにつれ劣化率 $\Delta \mu \mathrm{a} / \mu \mathrm{a}$ は漸隇し， $100 \mathrm{kHz}$ では 0.1 以下となる．他方，空隙が試料を貫通しない 限り，深さ $(0.3 \mathrm{~mm}$ 幅 $)$ による比透磁率 $\mu \mathrm{a}$ の劣化は周波数帯に よらず全般的に小さい，ただD試料では若干 $\Delta \mu \mathrm{a} / \mu \mathrm{a}$ の周波数 依存性が見られるが，これは高透磁率材料であり，構造敏感 な $\mu \mathrm{a}$ の材質的な特幑が残ったものと推定される.

\section{2 修復効果}

これら材料欠宿による磁気特性の劣化を回復する 1 つの方

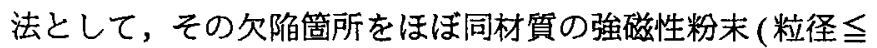
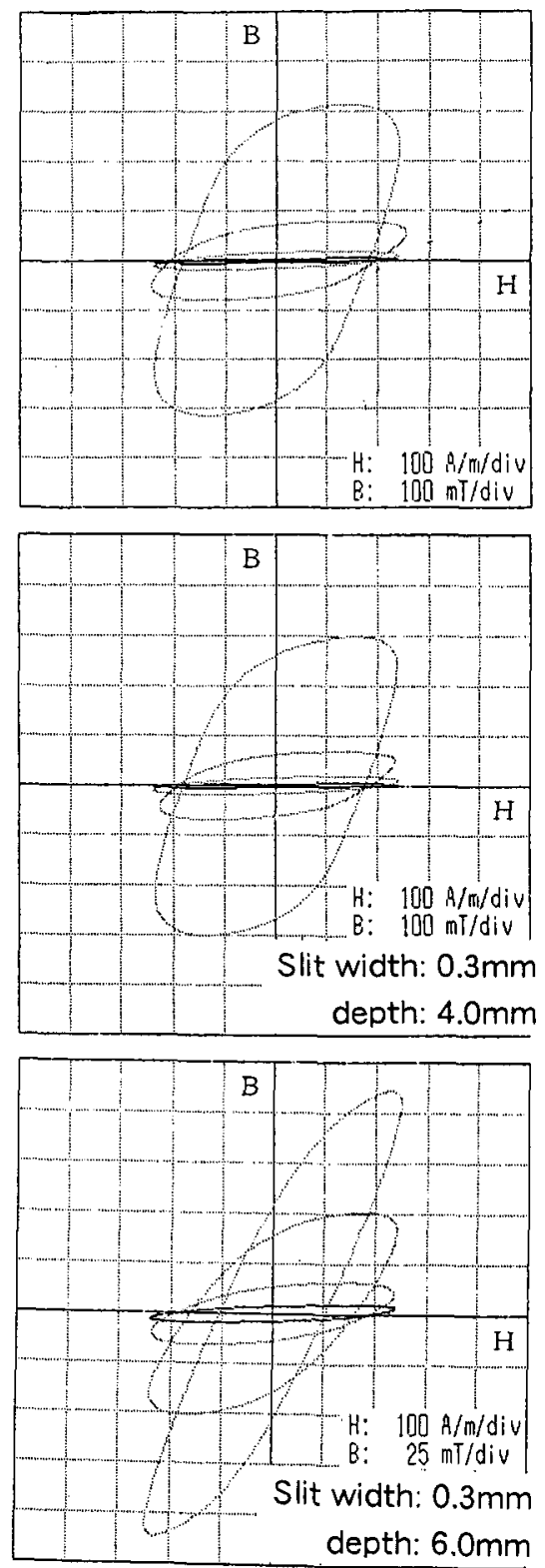

Fig.5 Example of AC B-H curves (C-type).
40 $\mathrm{m}$, Fig.8)で修復することを試みた。この際，水噴蓩粉末は 粒径が小さいほど球状化傾向が強くす，その分強磁性粉末の空 隙への充填性 ${ }^{9}$ がよいと推定される.

Fig.9，10はA〜D試料の磁束密度 $\mathrm{B}$ ，最大透磁率 $\mu \mathrm{m}$ の修復 による回復率 $\Delta \mathrm{B}^{\prime} / \Delta \mathrm{B}, \Delta \mu \mathrm{m}^{\prime} / \Delta \mu \mathrm{m}$ と空隙パラメーターとの関係 を示す.ここで $\Delta \mathrm{B}^{\prime}, \Delta \mu \mathrm{m}^{\prime}$ はもとの試料に対する修復時の特性 変化分であり，また便宜上，横軸の左端を $\Delta \mathrm{B}^{\prime} / \Delta \mathrm{B}, \Delta \mu \mathrm{m}^{\prime} /$ $\Delta \mu \mathrm{m}=0$ として原点にとって表した. 各試料とも磁束密度 B は 空隙の幅が広いほど, また深いほど回復率 $\Delta \mathrm{B}^{1} / \Delta \mathrm{B}$ にやや増加 の傾向が見られるものの，測定值のばらつきが大きい，この $\Delta \mathrm{B}^{\prime} / \Delta \mathrm{B}$ のばらつきは,粉末ペーストの充填不均一にもよるが, 対応するFig.3で劣化率 $\Delta \mathrm{B} / \mathrm{B}$ の值自体が小さいことに起因す ると考えられる.いずれにしても，回復率 $\Delta \mathrm{B}^{\prime} / \Delta \mathrm{B}$ は, Fig.3で 劣化率 $\Delta B / B$ の大きい $0.6,1 \mathrm{~mm}$ 幅の貫通孔に限れば 0.4 以上が 得られている. 他方, Fig.10の最大透磁率 $\mu \mathrm{m} の \Delta \mathrm{B}^{\prime} / \Delta \mathrm{B}$ は $\mathrm{A}$ 〜C試料(貫通孔)で 0.3 止り，D試料では 0.1 と読取れる.これ は空隙に充填された強磁性粉末の磁気的接触がそしく，孤立 した粒子のように振舞うため，直流磁界中では個々の粒子は 透磁率 $(\mu \mathrm{m})$, 従って磁束密度 B を減ずる強い反磁界をもつ ${ }^{10}$ ためと考えられる.実際，高透磁率材料のD試料では空腺パ

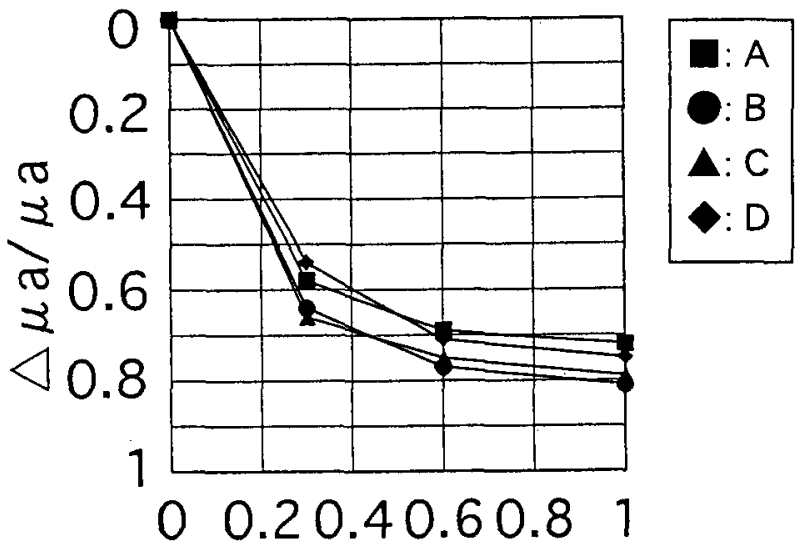

Slit width, $\mathrm{mm}$

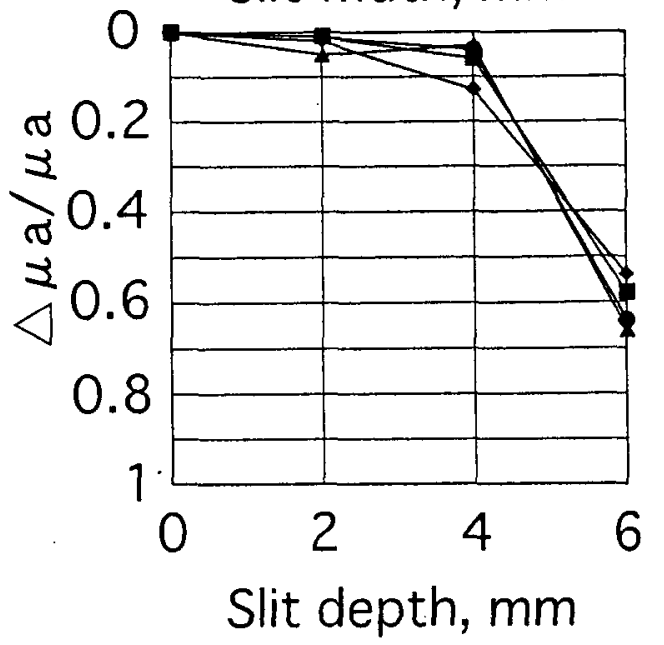

Fig.6 Effect of slit geometry on specific permeability $(\mu \mathrm{a})$ at $60 \mathrm{~Hz}$ magnetic field. 
ラメーターによらず，ほとんど回復傾向を示していない。

Fig.11にA〜D試料の $60 \mathrm{~Hz}$ における比透磁率 $\mu \mathrm{a}$ の修復によ る回復率 $\Delta \mu \mathrm{a}^{\prime} / \Delta \mu \mathrm{a}$ と空隙パラメーターとの関係を示す (表示 法はFig.10に同じ). 各試料とも $60 \mathrm{~Hz}$ での比透磁率 $\mu \mathrm{a}$ は貫通 した空隙を修復した状態では, 回復率は $\Delta \mu \mathrm{a}^{\prime} / \Delta \mu \mathrm{a} \sim 1 / 2$ とほぼ 一定で幅に依存しない. なお, 下図の空隙の深さによる回復 率が小さいのは, もとの Fig.6の劣化率 $\Delta \mu \mathrm{a} / \mu \mathrm{a}$ の影響を受け
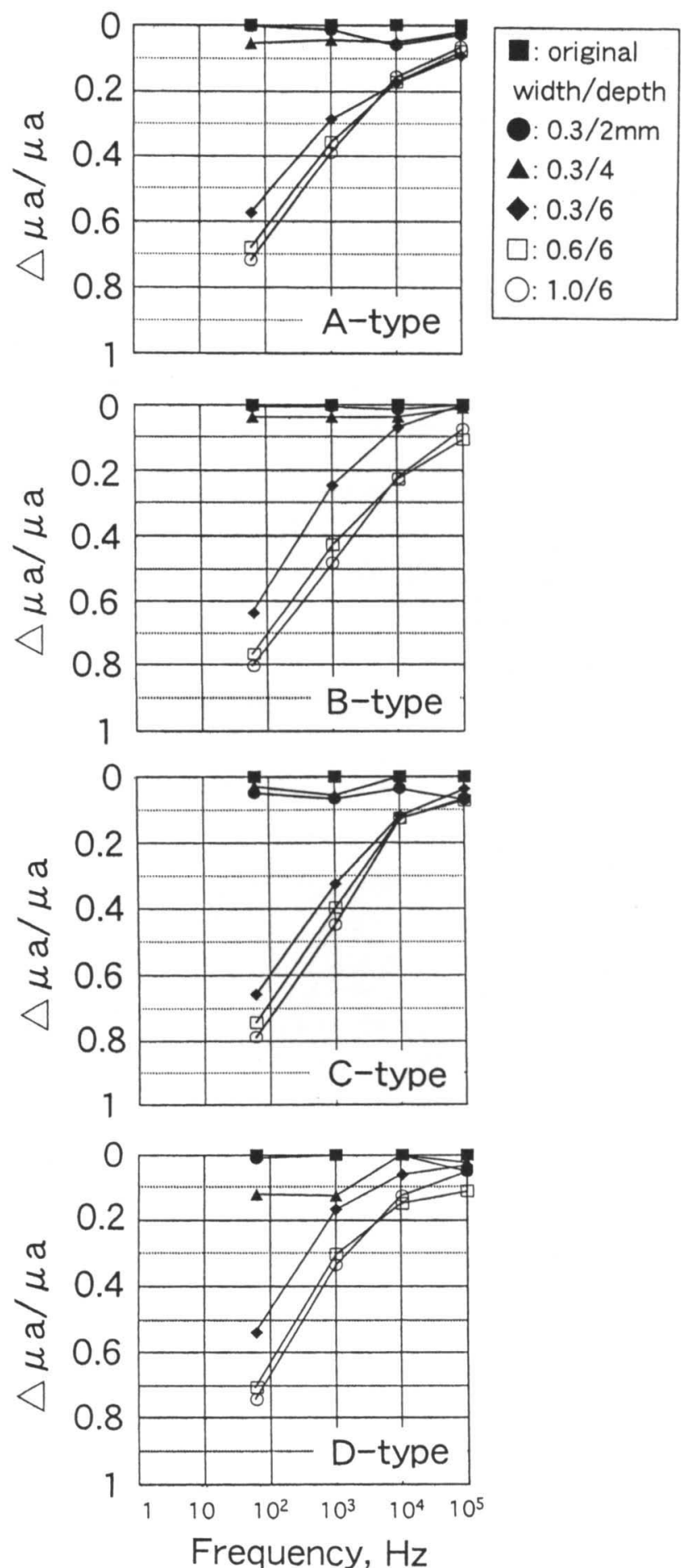

Fig.7 Change of specific permeability ( $\mu$ a) with frequency of applied field.

\section{ているものと解される.}

以上, 強磁性粉末ペーストによる空隙の修復効果はあまり 材質の影響を受けず, 直流磁界中では磁束密度 Bで, また $60 \mathrm{~Hz}$ の交流磁界中では比透磁率 $\mu \mathrm{a}$ で回復率にして $1 / 2$ 程度が 見込める.しかし Fig.7から明らかなように, $60 \mathrm{~Hz} \rightarrow 100 \mathrm{kHz}$ と高周波数域に入るほど空隙による劣化率は小さくなるため, 前記修復効果も相対的に小さく, 粉末ペースト充填の必要性 も減ずると判断される.

\section{4 結言}

4種類のソフト磁性合金を対象とした基本モデルにより,材 料欠陥 (痏)に伴う直流/交流磁気特性の劣化状況を調べ,さ らに久陷箇所に強磁性粉末ペーストを充填・修復した場合の 磁気特性 $(\mathrm{B}, \mu \mathrm{m}, \mu \mathrm{a})$ の回復状況について追究した.

基本的モデルの空隙による特性劣化は, 直流磁界中では磁 束密度 $(\mathrm{B})$ に比べ構造敏感な最大透磁率 $(\mu \mathrm{m})$ が大きく, 特に 高透磁率材料での特性劣化が大きい. 交流磁界中でも比透磁 率 $(\mu \mathrm{a} \propto$ 最大磁束密度 $\mathrm{Bm})$ は同様の劣化傾向を示すが, 高周 波数域になるほど劣化率は小さく, $100 \mathrm{kHz}$ では 0.1 以下とな る. また強磁性粉末ペーストによる磁気特性の欠損箇所の修 復効果は, 直流を含む低周波数側では回復率にして $1 / 2$ 程度見 込め, かつもとの劣化率自体も大きいため, この修復方法は

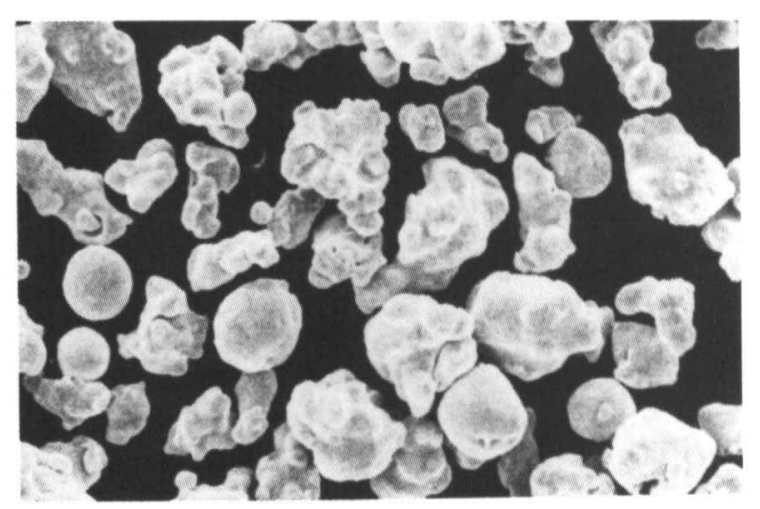

A-type

Atomized/reduced powder

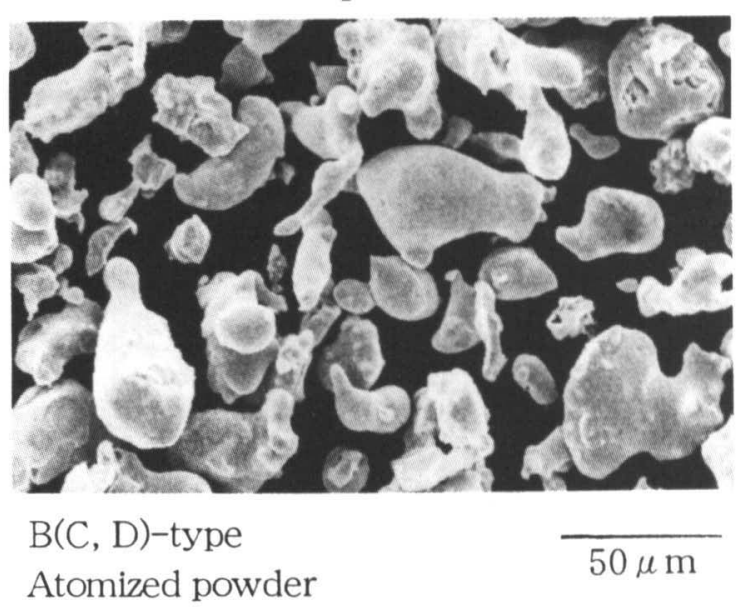

Fig.8 SEM-images of ferromagnetic powders ( $\leqq 40 \mu \mathrm{m})$. 

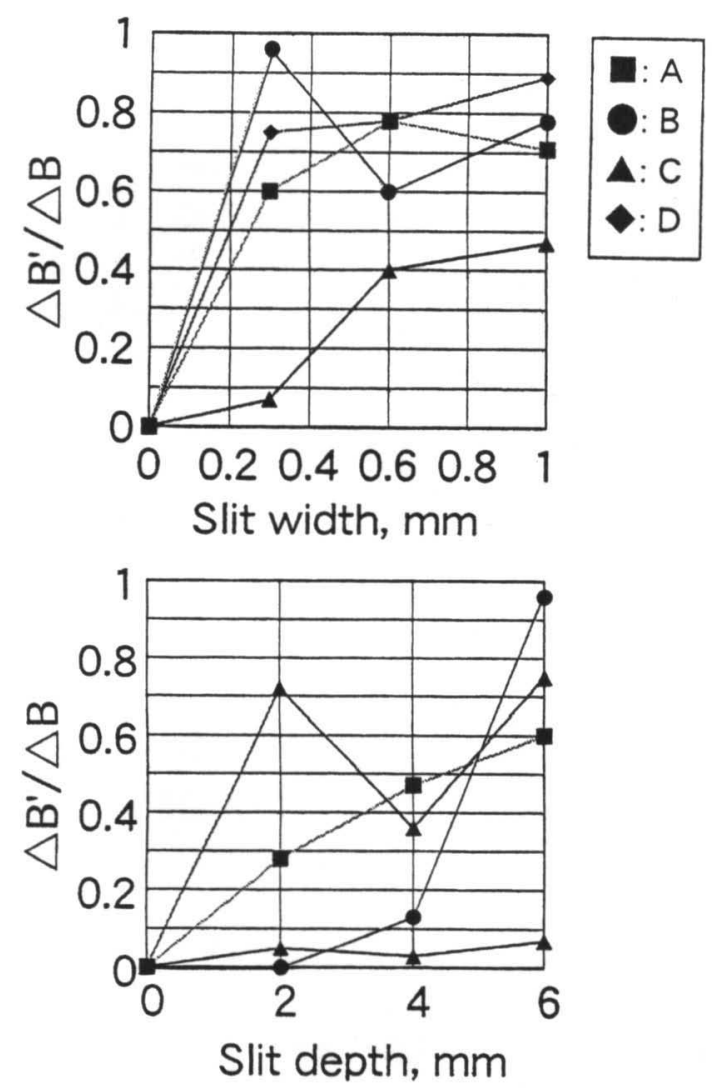

Fig.9 Effect of paste filling to slit on magnetic induction (B).
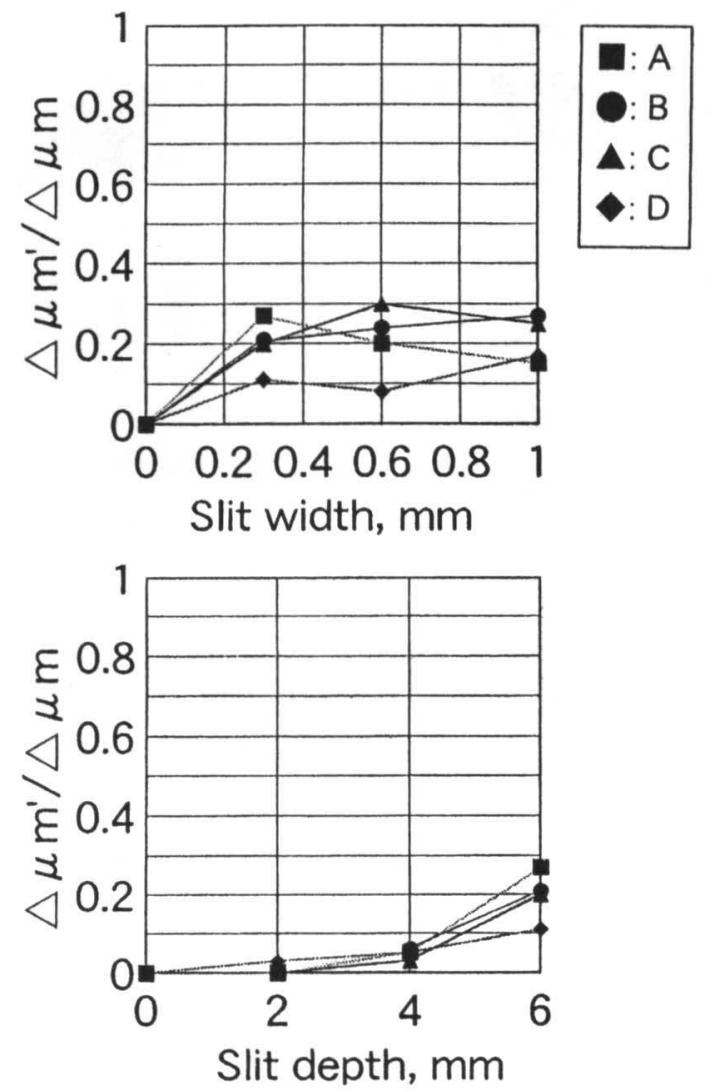

Fig.10 Effect of paste filling to slit on maximum permeability $(\mu \mathrm{m})$.
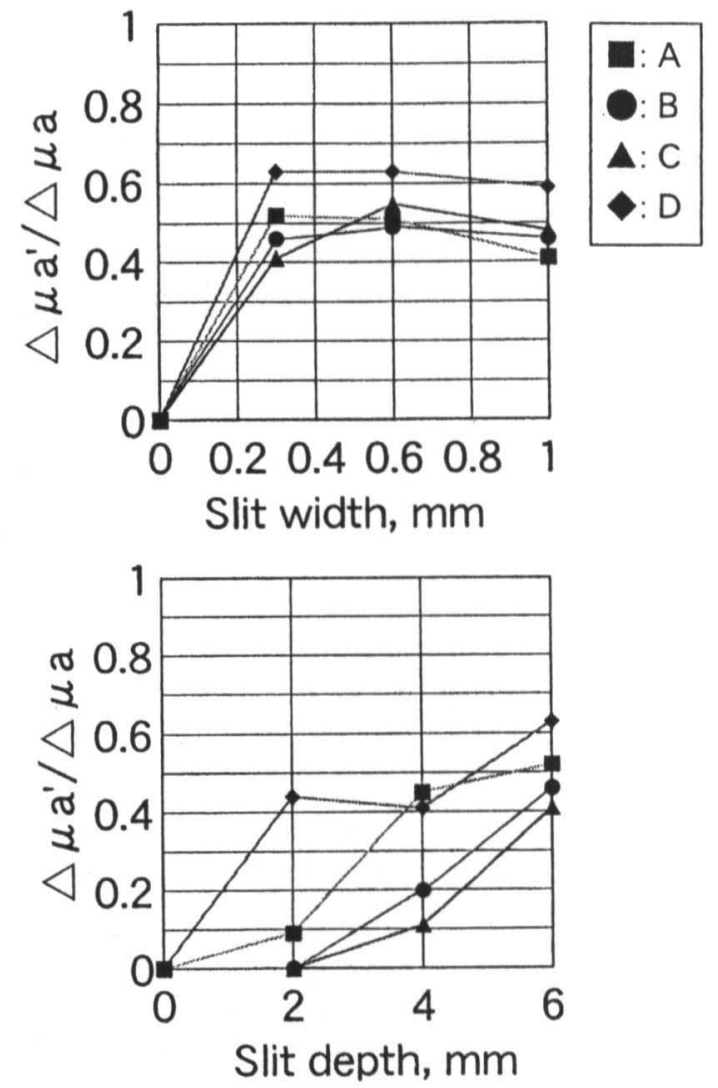

Fig.11 Effect of paste filling to slit on specific permeability $(\mu a)$ at $60 \mathrm{~Hz}$ magnetic field.

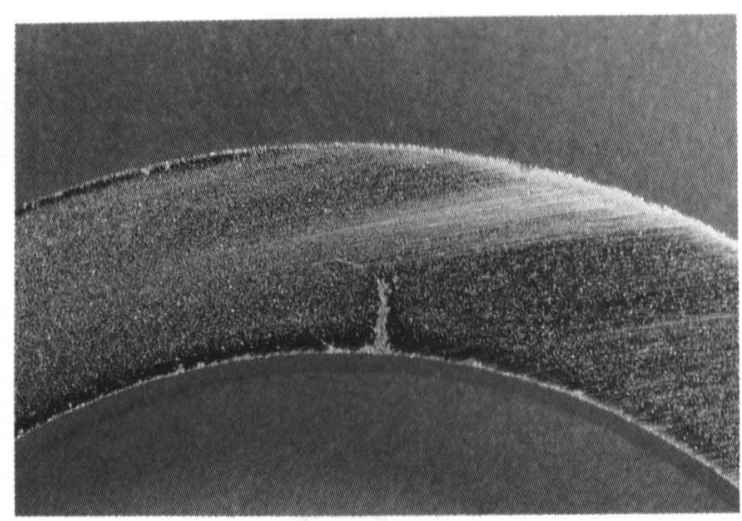

Fig.12 Example of extraneous defect of $\mathrm{P} / \mathrm{M}$ parts.

より有効であると判断される.この種の材料欠陥は通常, 粉 末治金や射出成形品にも見られる (例, Fig.12) が, エヤー ギャップという観点から, 本研究では粉末焼結体中の残留気 孔と材料欠陥との交絡作用を避けるため, 敢えて環状試験片 に溶製材を使用した. さらに粉末焼結体に内在する残留気孔 を考虑に入れた材料欠陥の，磁気特性の劣化現象への影響に ついても調查が必要と思われる.

最後に本研究を進めるにあたりご協力を頂いた大同工業大 学尾畑智光氏並びに大同特殊鋼(侏技術開発研究所の関係者の 方々に深く謝意を表する。 
文献

1) 加藤哲男 : 技術者のための磁気・磁性材料, 日刊工業新聞 社, (1991)193.

2) 近角総信ほか: 磁性体ハンドブック,朝倉書院,(1975)129, 879.

3) 加藤哲男, 関尾 勲, 草加勝司: " 快削性電磁ステシレス ", 電気製鋼，41(1970)127-132.

4) 斎藤章彦, 矢萩慎一郎: " $\mathrm{Fe}-\mathrm{Cr}-\mathrm{Al}$ 系電磁ステンレス鋼の特 性について ", 電気製鋼, 61(1990)183-192.

5) 大貫繁雄, 安達三郎: 電気磁気学, 森北出版, (1988)118.

6) 本蔵義信, 藤井秀樹: "軟磁性ステンレス鋼のパルス応答性
に及ぼすCrおよび Al 量の影響", 鉄と鋼, 77(1991)840-847.

7) 草加勝司,鈴木智也,近藤鉄也: "フエライト系ステンレス 鋼の交流磁気特性に及ぼす残留気孔の影響",粉体および粉 末治金, 45(1998)685-691.

8）草加勝司: "高合金粉末の製造技術とその応用", 粉体およ び粉末治金, 33(1986)387-397.

9) H.H.Hausner: "Friction Conditions in a Mass of Metal Powder", Int. J. Powder Met., 3(1967)7-13.

10) P.Ruuskanen and O.Heczko: "Mechanical Alloyed Fe-B, Fe-Si and Fe-B-Si Powders", Key Eng. Mater., 81(1993)159-168. 